\title{
The effect of simulated sheep grazing on male and female reproductive performance in Caragana microphylla Lam. (Leguminosae)
}

\author{
Zhen Zhang ${ }^{\mathrm{a}, \mathrm{c}, *}$, Lichao Wang ${ }^{\mathrm{a}}$, Jing Liu ${ }^{\mathrm{a}}$, Zhaorong Dong ${ }^{\mathrm{a}}$, Wei Xu ${ }^{\mathrm{a}}$ and Shiping Wang ${ }^{\mathrm{b}}$ \\ ${ }^{a}$ Resources Environment College, Anhui Agricultural University, Hefei 230036, China \\ ${ }^{b}$ Institute of Tibetan Plateau Research, Chinese Academy of Sciences, Beijing 100101, China \\ ${ }^{c}$ Hefei Scientific Observing and Experimental Station of Agro-Environment, Ministry of Agriculture, Hefei 230036, China
}

\begin{abstract}
Understanding the reproductive response of host plants to herbivores is important in grazing ecology and grassland management. Simulated grazing experiments were conducted to determine the influence of different grazing intensities on reproductive performance of a shrub, Caragana microphylla Lam. The total leaf mass, total flower mass, total flower mass allocation, and single flower mass allocation decreased with increased grazing intensity. The total spine mass, single flower mass and total spine mass allocation increased with increased grazing intensity. The stem mass, stem mass allocation and total leaf mass allocation had not significant change with the increasing grazing intensity. Under heavy grazing treatments, the host plants significantly decreased their investment in reproduction and increased investment in physical defense organs. Although there were no significant differences in the number of ovules among different grazing intensities, herbivory negatively affected reproductive performance, including the number of flowers, the number of pollen grains per flower, the number of ripe seeds and the rate of pod-set in host plants. These results indicate that there are trade-offs among vegetative and reproductive and defensive organs. Compared with male reproduction, female reproductive performance was less sensitive to herbivory and grazing intensity. Moreover, pollen grains from heavily browsed plants seemed to be less likely to sire pods and ripe seeds than those from unbrowsed plants, indicating that herbivory not only decreased pollen production, but also adversely affected pollen performance.
\end{abstract}

Keywords Caragana microphylla; herbivory; Inner Mongolia steppe; reproduction; saliva; trade-off

\section{Introduction}

The relationship between animal and plant is one of the important aspects of research in ecology (Nagaike, 2012; Massad, 2013). For individual plants, herbivore leads not only to a loss of photosynthetic area, but also to a loss of stored nutrients that would otherwise be available for growth and reproduction (Quesada et al., 1995; Mundim et al., 2012). Therefore, grazing animals can affect plant metabolism, growth and reproduction (Rebek and O'Neil, 2005). Several studies have provided experimental evidence of the morphological and secondary metabolic response of host plants to herbivory (Maleck and Dietrich, 1999; Sell, 2000; Brookshire et al., 2002; Musser et al., 2012; Francois, 2013). However, these browsing studies were based only on one stocking rate, and few considered differences in sexual reproduction (Rebek and $\mathrm{O}^{\prime} \mathrm{Neil}$, 2005; Zhang, 2017).

Reproduction is an important stage of plant lifehistory (Buchanan and Underwood, 2013), and compensatory growth may happen if the plant is browsed. Therefore, compensatory growth is produced by browsed plants at the expense of sexual reproduction (du Toit and Olff, 2014). Many reports have described the effects of herbivory on the reproduction of host plants, such as flowering phenology (Brody, 1997; Juenger and Bergelson,
1997; van Kleunen et al., 2004), the number of flowers and flower size (Krupnick and Weis, 1999), sexual expression (Leather, 2000), fruit-set and seed-set (Mueller et al., 2005), indicating that herbivory negatively affects plant reproduction (Stephenson, 1982; Schemske, 1988; Krupnick and Weis, 1999; Maschinski, 2001). Yet, there is little information on the effects of herbivory on pollen quality.

We explored the mechanisms through which a simulated sheep grazing experiment affected male and female reproductive success in a perennial shrub, Caragana microphylla Lam. C. microphylla is a widely distributed shrub species in the northern steppe and agro-pastoral ecotone of China, and propagate through sexual reproduction (He et al., 2010). In these regions, C. microphylla has a great ecological and economic value, and plays a key role in vegetation succession from active dune to sandy grassland (Zhang, 1994). C. microphylla is a perennial xerophytic shrub with a plant height of $40-70 \mathrm{~cm}$, stipules persistent, hardened needle-like, pinnate compound leaves, solitary yellow flowers, bell-shaped calyx and cylindrical pods (Cong, 2017). Generally, it germinates in mid-early April, spreads its leaves in mid-early May, blooms in midlate May, bears fruit in mid-early June and matures in midlate July. 
The objective of our study was to estimate three aspects of herbivore effects on the reproduction of C. microphylla. First, what effects do different grazing intensities exert on biomass allocation of the plant? Second, do male and female reproductive performances respond differently to grazing intensity? Third, does herbivory affect the success of reproduction, especially, pollen quality?

\section{Materials and methods}

\section{Study area}

The Inner Mongolia Grassland Ecosystem Research Station established an experimental grazing field in 1989. It is located at Bayan Siler County, Xilinhot City (N4337', E116 $\left.{ }^{\circ} 43^{\prime}\right)$, mostly at an elevation of $1000 \mathrm{~m}$ above sea level or more ( $\mathrm{Li}$ et al., 1999). The regional climate is continental, with a 30-year average annual rainfall of approximately $350 \mathrm{~mm}(200-500 \mathrm{~mm}), 60$ to $70 \%$ of which falls between July and August. Annual mean temperature is $-0.4^{\circ} \mathrm{C}$, and average monthly temperature is $-23^{\circ} \mathrm{C}$ in January and $17.9^{\circ} \mathrm{C}$ in July. There are 150 to 180 favorable days for plant growth per year. The predominant plant species are Artemisia frigida Willd. (Asteraceae) and Cleistogenes squarrosa (Trin.) Keng (Poaceae) (Wang et al., 2001). Grazing plots were set up using a randomized complete block design with different grazing intensities, namely no grazing, light grazing, moderate grazing, and over grazing, and each treatment had three $1 \mathrm{hm}^{2}$ plots (Wang et al., 1998). Inner Mongolian fine sheep were used in the experiment every year during the warm seasons from May 20 to October 5 from 1989 to 2012 .

\section{Plant materials}

C. microphylla is a typical $\mathrm{C}_{3}$ legume shrub with compound leaves and spines in its stem, varying in height from 0.3 to $1.3 \mathrm{~m}$ depending on grazing intensity, and shows great resistance to ungulate herbivory. Adult plants of $C$. microphylla blossom out many simple flowers in its stem very early in June, which will stand for about 10 days. In the host plant flower, ten stamens pose diadelphous stamen and there are one carpel and one locule, but the number of ovules in its ovary is variable. Male and female organs mature at nearly the same time. Flowers of C. microphylla are self-incompatible and require pollinator visitation or wind agitation to set pod and seed (Xu et al., 1988). Pods mature in early September.

\section{Experimental design}

The grazing experiment was ceased in 2012, after which we simulated grazing by applying sheep saliva in the experiment so as to control the defoliation intensity of C. microphylla. Twenty shrubs in each grazing intensity plot were chosen randomly and tagged. Different defoliation intensities were simulated by clipping an appropriate length of stems on May 20 in 2012. In the light grazing plot, we removed $20 \%$ of stem length to simulate light grazing (LB), $35 \%$ for moderate grazing (MB) and 55\% for heavy grazing (HB).

In terms of the effect of saliva on plant growth (Zhang et al., 2007), we clipped the chosen branches and applied saliva immediately. Sheep saliva was collected by inserting a sponge into the mouth of a two-year old wether at the experimental site. The sponge was sterilized with $70 \%$ alcohol and then dried before used. When enough saliva had been collected in a tube, the chosen plants were clipped and saliva was applied immediately to the damaged parts. About $1.5 \mathrm{ml}$ saliva was applied to each branch.

To estimate the biomass allocation of the shrub, 10 branches of different individual shrubs of similar diameter were chosen and tagged in four grazing densities (no grazing (NB), LB, MB and HB) on May 31, 2012. On 10 June, when the host plant was in bloom, we clipped $10 \mathrm{~cm}$ length branches (excluding the annual branches) and divided them into four parts, namely the stem, leaf, flower, and spine. Then all samples were oven-dried at $65^{\circ} \mathrm{C} 48 \mathrm{~h}$ to a constant weight. At the same time, we collected and counted the pollen from 10 flowers produced on 10 experimental branches in each plot in order to estimate male reproductive performance. We carefully removed anthers from flower buds and developing anthers (prior to pollen dehiscence) were pulled from the corolla using fine-point tweezers. The anthers removed from each flower were placed into a labeled $1.5 \mathrm{ml}$ open Eppendorf tube in a closed dry cabinet. On June 25 , tubes were sealed in $1 \% \mathrm{NaCl}$ solution and samples were later processed and counted using a hemocytometer with a microscope (Solomon, 1986). Then we quantified the total number of pollen grains produced per flower.

On June 10, we counted the number of flowers on 10 $\mathrm{cm}$ length branches on another 10 branches chosen in each plot. In order to ensure that pollen is derived from the same treatment conditions and to avoid pollen of other treatments, when estimate the pod-set and seed-set for each treatment, flowers were emasculated and pollinated by rubbing dehiscing anthers from other plants onto their stigmas, and were then bagged. The pollen donor was several meters away from the pollen recipient in a plot of the same grazing density. After the flowers withered, they were sprayed with insecticide to prevent insects grazing the pods. Mature pods were collected from each chosen branch prior to pod dehiscence (September, 5-15). The number of pods, seeds in undeveloped ovules, aborted seeds and ripe seeds in each pod were counted (the total ovule number per pod being the sum of the latter three variables). We randomly selected a sample of 20 seeds from each plot with 10 replications to estimate mean seed mass. The rate of pod-set per chosen branch was calculated as the ratio of mature pods to the total number of flowers. The rate of seed set was calculated as the ratio of the number of ripe seeds to the total number of ovules per pod.

To determine the effect of different grazing intensities on pollen performance, outcrossing rates were compared for 3 plants between NB and HB treatments. We chose and tagged 45 flowers from three plants in each plot, then the following treatments were applied: (1) open pollination 
Table 1. Results of one-way ANOVA for the effect of different browsing intensities on biomass allocation of chosen branches.

\begin{tabular}{lccccc}
\hline Variable & $F\left(\mathrm{df}_{1}, \mathrm{df}_{2}\right)$ & No browsing & Light browsing & Moderate browsing & Heavy browsing \\
\hline Stem mass & $0.912(3,12)$ & $0.466 \pm 0.012 \mathrm{a}$ & $0.457 \pm 0.085 \mathrm{a}$ & $0.468 \pm 0.008 \mathrm{a}$ & $0.466 \pm 0.033 \mathrm{a}$ \\
Total leaf mass & $3.4(3,12)^{*}$ & $0.318 \pm 0.033 \mathrm{a}$ & $0.245 \pm 0.011 \mathrm{ab}$ & $0.245 \pm 0.020 \mathrm{ab}$ & $0.210 \pm 0.004 \mathrm{~b}$ \\
Total spine mass & $45.04(3,12)^{* *}$ & $0.037 \pm 0.002 \mathrm{~d}$ & $0.057 \pm 0.002 \mathrm{c}$ & $0.145 \pm 0.009 \mathrm{~b}$ & $0.193 \pm 0.005 \mathrm{a}$ \\
Total flower mass & $6.698(3,12)^{*}$ & $0.424 \pm 0.039 \mathrm{a}$ & $0.310 \pm 0.035 \mathrm{a}$ & $0.340 \pm 0.110 \mathrm{a}$ & $0.123 \pm 0.024 \mathrm{~b}$ \\
Single flower mass & $5.488(3,12)^{*}$ & $0.024 \pm 0.002 \mathrm{~b}$ & $0.017 \pm 0.001 \mathrm{~b}$ & $0.022 \pm 0.005 \mathrm{~b}$ & $0.041 \pm 0.011 \mathrm{a}$ \\
Stem mass allocation & $0.318(3,12)$ & $0.373 \pm 0.021 \mathrm{a}$ & $0.421 \pm 0.012 \mathrm{a}$ & $0.394 \pm 0.044 \mathrm{a}$ & $0.423 \pm 0.079 \mathrm{a}$ \\
Total leaf mass allocation & $1.962(3,12)$ & $0.249 \pm 0.016 \mathrm{a}$ & $0.226 \pm 0.014 \mathrm{a}$ & $0.201 \pm 0.003 \mathrm{a}$ & $0.208 \pm 0.018 \mathrm{a}$ \\
Total spine mass allocation & $31.27(3,12)^{* *}$ & $0.030 \pm 0.002 \mathrm{~d}$ & $0.053 \pm 0.003 \mathrm{c}$ & $0.123 \pm 0.019 \mathrm{~b}$ & $0.193 \pm 0.024 \mathrm{a}$ \\
Total flower mass allocation & $7.148(3,12)^{* *}$ & $0.330 \pm 0.019 \mathrm{a}$ & $0.285 \pm 0.028 \mathrm{a}$ & $0.266 \pm 0.065 \mathrm{a}$ & $0.127 \pm 0.037 \mathrm{~b}$ \\
Single flower mass allocation & $6.295(3,12)^{*}$ & $0.018 \pm 0.001 \mathrm{a}$ & $0.158 \pm 0.001 \mathrm{a}$ & $0.017 \pm 0.002 \mathrm{a}$ & $0.048 \pm 0.012 \mathrm{~b}$ \\
\hline
\end{tabular}

${ }^{*}$ The mean difference is significant at the 0.05 level $;{ }^{* *}$ The mean difference is significant at the 0.001 level. The different letter within a row indicates the significant difference at the 0.05 level. $\mathrm{DF}_{1}$ is the freedom of between groups; $\mathrm{DF}_{2}$ is the freedom of within groups.

Table 2. Partial correlation matrix among all counted biomass modules for Caragana microphylla under different browsing intensities.

\begin{tabular}{lcccc}
\hline Variable & $\begin{array}{l}\text { Stem } \\
\text { mass }\end{array}$ & $\begin{array}{l}\text { Total leaf } \\
\text { mass }\end{array}$ & $\begin{array}{l}\text { Total spine } \\
\text { mass }\end{array}$ & $\begin{array}{c}\text { Total flower } \\
\text { mass }\end{array}$ \\
\hline Total leaf mass & 0.036 & & & \\
Total spine mass & -0.207 & $-0.521^{*}$ & & \\
Total flower mass & -0.159 & $0.400^{*}$ & $-0.472 *$ & \\
$\begin{array}{l}\text { Single flower } \\
\text { mass }\end{array}$ & -0.153 & -0.202 & $0.599^{*}$ & -0.197 \\
\hline
\end{tabular}

${ }^{*}$ Correlation is significant at the 0.05 level $;{ }^{* *}$ Correlation is significant at the 0.01 level.

$\left(\mathrm{T}_{0}\right)$ : flowers were neither emasculated nor bagged; (2) hand pollination with pollen from the same grazing intensity plots $\left(\mathrm{T}_{1}\right)$ : flowers were emasculated, pollinated by rubbing dehiscing anthers from other plants onto their stigmas, and bagged; the pollen donor was several meters away from the pollen recipient and was chosen in the same plot as the recipient; and (3) hand pollination with pollen from the other grazing intensity plots $\left(\mathrm{T}_{2}\right)$ : flowers were emasculated, pollinated by rubbing dehiscing anthers from a plant in another plot onto their stigma, e.g., the stigma of an NB plant received pollen grains from HB plants. To avoid receiving pollen from other flowers, the treated flowers need to be bagged. When flowers were emasculated with tweezers, the anthers were developing and the pollen was not dehiscent during the experimental period. This process was performed carefully with no damage to floral development. Tweezers were cleaned by swabbing with an alcoholsoaked cloth before moving between treated flowers, and the pollen from one flower is strictly forbidden to be pollinated on different flowers. Bags were removed after flower senescence to minimize the negative effects of bagging on pod development. On September 10, when pods were fully developed, they were counted and taken to the laboratory for determination of the number of seed and seed-sets.

\section{Data analysis}

To estimate biomass allocation, all data on the rates of pod and seed-set, and pollen production, were statistically analyzed using the one-way ANOVA procedure of SPSS version 10.0 (Chicago, IL, USA). Before the analysis, we conducted a diagnostic test of normal distribution and homoscedasticity, and the result is very satisfactory. In addition, to estimate the difference of experimental traits among different grazing intensities, post-hoc multiple comparisons were performed using Tukey B test (Tukey`sb) at 0.05 level. Correlation coefficients for the biomass of host plants in different modules were calculated using partial correlation.

When estimating the effects of pollination experiments, data were statistically analyzed using a two-way ANOVA procedure with Type III sums of squares to test the effects of both grazing intensity (NB and $\mathrm{HB}$ ) and different pollen donor (pollen from NB or HB anthers) on female performance, such as the rate of pod-set and seed-set. In addition, correlations between the parameters tested were analyzed using Pearson's correlation matrix.

\section{Results}

\section{Biomass allocation}

On the branches chosen, both total leaf and flower biomass decreased with grazing intensity and the only significant difference of the two index was observed between NB and HB treatments $\left(F_{3,12}=3.4, P=0.034 ; \mathrm{F}_{3,12}=6.698, \mathrm{P}=\right.$ 0.023 , respectively), whereas total spine biomass significantly increased with increasing grazing intensity $\left(F_{3,12}\right.$ $=45.04, P<0.001)($ Table 1). Therefore, host plants that were heavily browsed significantly decreased investment in vegetative (leaves) and reproductive (flowers) organs at the cost of an increase in defensive investment (spines). Significantly negative correlations were found between the biomass of vegetative and defensive $\operatorname{organs}(R=-0.521$, $P=0.015$ ) (Table 2). Although herbivory evidently influenced the total number of flowers (Table 1), the single flower mass of HB plants was significantly higher than that of the three other grazing intensities $\left(F_{3,12}=5.488\right.$, $P=0.013)$. These results indicate trade-offs among the vegetative, reproductive, and defensive modules for C. microphylla under grazing.

\section{Male and female reproductive performances}

Grazing intensity affected the reproductive performances of male and female organs (Table 3 ). There were significant 
Table 3. Results of one-way ANOVA for the effect of browsing intensity on sexual reproduction.

\begin{tabular}{lccccc}
\hline Variable & $F\left(\mathrm{df}_{1}, \mathrm{df}_{2}\right)$ & No browsing & Light browsing & Moderate browsing & Heavy browsing \\
\hline Number of flowers & $89.99(3,15)^{* *}$ & $18.80 \pm 0.41 \mathrm{a}$ & $18.00 \pm 0.82 \mathrm{ab}$ & $15.50 \pm 1.43 \mathrm{~b}$ & $3 \pm 0.63 \mathrm{c}$ \\
Rates of pod-set & $11.903(3,15)^{* *}$ & $0.79 \pm 0.02 \mathrm{a}$ & $0.78 \pm 0.01 \mathrm{a}$ & $0.70 \pm 0.04 \mathrm{a}$ & $0.29 \pm 0.07 \mathrm{~b}$ \\
Number of pollen grains per flower & $3.242(3,36)^{*}$ & $63125 \pm 2214.614 \mathrm{a}$ & $53500 \pm 3578.49 \mathrm{ab}$ & $51500 \pm 4349.33 \mathrm{~b}$ & $46500 \pm 1848.94 \mathrm{~b}$ \\
Number of ovules per flower & $3.41(3,31)$ & $17.12 \pm 0.74 \mathrm{a}$ & $16.85 \pm 0.78 \mathrm{a}$ & $17.48 \pm 0.42 \mathrm{a}$ & $18.24 \pm 0.66 \mathrm{a}$ \\
Number of ripe seeds per pod & $12.269(3,31)^{* *}$ & $5.30 \pm 0.19 \mathrm{a}$ & $3.14 \pm 0.35 \mathrm{~b}$ & $3.20 \pm 0.65 \mathrm{bc}$ & $2.56 \pm 0.40 \mathrm{c}$ \\
Seed mass (mg) & $24.67(3,16)^{* *}$ & $2.5 \pm 0.57 \mathrm{a}$ & $2.1 \pm 0.1 \mathrm{~b}$ & $2.0 \pm 0.12 \mathrm{bc}$ & $1.9 \pm 0.1 \mathrm{c}$ \\
\hline
\end{tabular}

${ }^{*}$ The mean difference is significant at the 0.05 level; ${ }^{* *}$ The mean difference is significant at the 0.01 level; The different letter within a row indicates the significant difference at the 0.05 level. $\mathrm{DF}_{1}$ is the freedom of between groups; $\mathrm{DF}_{2}$ is the freedom of within groups.

differences between NB and HB treatments for most of the variables measured. However, there was no significant difference in the number of ovules per flower among the four grazing intensities $\left(F_{3,31}=3.41, P=1.28\right)$. Compared with $\mathrm{NB}$, the number of pollen grains in $\mathrm{MB}$ and $\mathrm{HB}$ was significantly reduced $\left(F_{3,36}=3.242 ; P=0.041,0.004\right.$, respectively), they were reduced by $18.42 \%$ and $26.34 \%$, respectively (Table 3 ).

\section{Pollen performance}

For NB plants, $T_{1}$ pollination significantly increased the rate of pod-set and the number of ripe seeds compared with $\mathrm{T}_{2}$ pollination treatment $(P=0.007)$ (Fig. 1). However, for the HB treatment, the rate of pod-set and the number of ripe seeds in $T_{2}$ treatments were 1.54 and 1.63 times greater than under $\mathrm{T}_{1}$ pollination, respectively (Fig. 1). In addition, there were no significant differences between $\mathrm{T}_{0}$ and $\mathrm{T}_{1}$ pollination treatments $(P=0.057,0.188$, respectively) for HB plants (Fig. 1) and pollination method did not significantly influence the number of ripe seeds $(P=0.342)$ for NB plants (Fig. 1). Heavy grazing significantly decreased the rate of pod-set and the number of ripe seeds for both open and $T_{1}$ treatments, whereas there were no significant differences between NB and HB treatments for $\mathrm{T}_{2}$ pollination $(P=$ 0.31, 0.698, respectively; Fig. 1).

Interactive effects of grazing intensity and pollination method on the rate of pod-set and number of ripe seeds were observed (Table 4). From the partial Eta squared results, these effect were influenced to a greater extent by grazing intensity than by pollination method (for rate of podset, $\mathrm{Eta}_{\text {grazing intensity }}^{2}=0.749>\mathrm{Eta}^{2}{ }_{\text {pollination }}=0.599$; for ripe seed, $\left.\mathrm{Eta}_{\text {grazing intensity }}^{2}=0.253>\mathrm{Eta}_{\text {pollination }}^{2}=0.187\right)$.

\section{Discussion}

In a browsing environment, grazing usually stimulates host plants to invest more resources in defensive organs (Simms and Rausher, 1987) and compensatory growth (Noy-Meir, 1993; Wang et al., 2015 ). In our study, similar results were found for the biomass of leaves and flowers of the host plant, C. microphylla, decreased, and the biomass of spine and single flower increased with the increase in grazing intensity (Table 1). The total flower biomass and the number of flowers of the host plant are significantly decreased under heavy grazing, but the single flower biomass increased. Mainly as a result of the reallocation of available resources, this adaptive grazing strategy is a trade-off
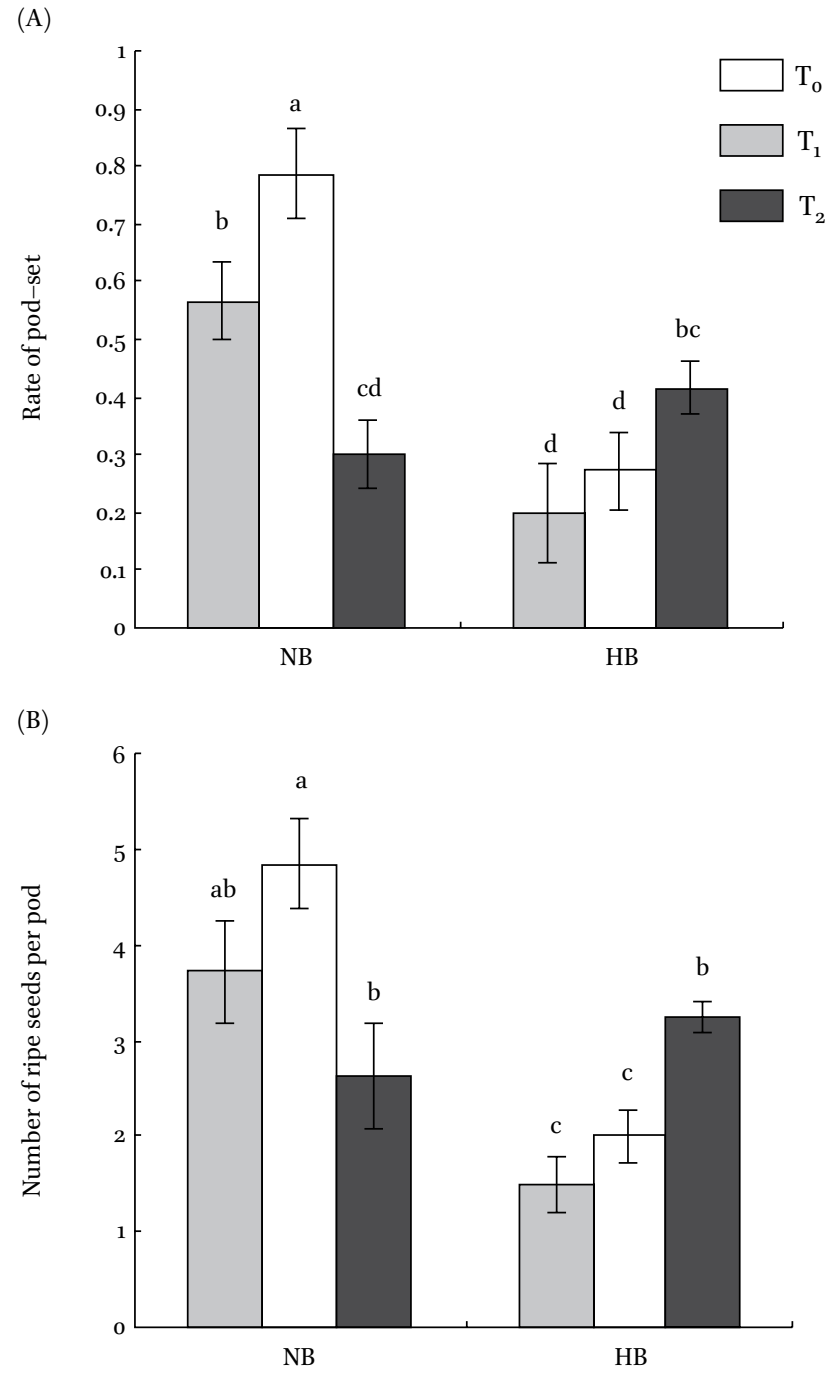

Browsing intensity

Figure 1. The effects of different pollination treatments on the pollen performance of C. microphylla. (A) the rate of pod-set and (B) number of ripe seeds produced of $C$. (HB microphylla in no-browsing (NB) and heavy-browsing (HB) plots (mean $\pm 1 \mathrm{SE}, \mathrm{df}=17,72$ ). ${ }^{*}$ Grey bars, $\mathrm{T}_{0}$ (open pollination); White bars, $\mathrm{T}_{1}$ (hand pollination with pollen from plots of the same browsing intensity); black bars, $\mathrm{T}_{2}$ (hand pollination with pollen from plots of different browsing intensity). Bars are standard errors. The treatments with the same letter are not significantly different at $P=0.05$.

strategy for plants to survive which reduce the efficiency of plant sexual reproduction caused by total flowers and total flower biomass (Feller, 1996). Wang et al. (2015) showed that plants avoid excessive grazing damage to their growth 
Table 4. The effect of browsing intensity and hand pollination on pod-set per experimental branch and number of ripe seed per pod. Data is obtained through correlation analysis.

\begin{tabular}{|c|c|c|c|c|c|}
\hline \multirow[t]{2}{*}{ Factors } & \multirow[t]{2}{*}{ d.f. } & \multicolumn{2}{|c|}{ Pod-set per experimental branch } & \multicolumn{2}{|c|}{ Number of ripe seed per pod } \\
\hline & & $F$ & Partial Eta ${ }^{2}$ & $F$ & Partial Eta ${ }^{2}$ \\
\hline Browsing intensity & 1 & $35.89^{* *}$ & 0.749 & $15.21^{* *}$ & 0.253 \\
\hline Hand pollination & 2 & $8.98^{* *}$ & 0.599 & $5.03^{*}$ & 0.187 \\
\hline $\begin{array}{l}\text { Browsing intensity } \\
\times \text { hand pollination }\end{array}$ & 2 & $13.81^{* *}$ & 0.697 & $4.49^{*}$ & 0.166 \\
\hline Error (d.f.) & & $0.02(12)$ & & $1.588(12)$ & \\
\hline
\end{tabular}

The residual mean squares with their degrees of freedom in parentheses are also given in the bottom row. ${ }^{*}$ Correlation is significant at the 0.05 level; ${ }^{* *}$ Correlation is significant at the 0.01 level.

by increasing their investment in thorns (compensatory growth). Rusch et al. (2009) also suggest that grazing significantly reduces the traits of the plants, including the biomass of the entire plant, the biomass of the leaves, the biomass of the stems, and the biomass of the seeds.

Sexual reproduction is considered to be an important carbon sink for plants. (Gowda and Palo, 2003). Due to grazing, the plant photosynthetic organs were damaged (Krupnick and Weis, 1999; Milchunas and Sternberg, 2011), and the available resources of sexual reproduction of plants were reduced (Pollice et al., 2013; González-Megías, 2016). Herbivory negatively influenced male and female reproductive performance (Juenger, 2000). In this research, the number of flowers and pollen grains decreased with the increase of grazing intensity, while the ovules did not change significantly (Table 3 ). The results were consistent with the performance of Isomeris abrorea, whose performance of male reproduction was found to be far stronger than its female reproduction when browsed (Krupnick and Weis, 1999). This is because ovules are packaged in the ovaryand are not easily influenced by the environment (Knight et al., 2005), while pollen directly emerges from the anthers and can be browsed by herbivores. Therefore, a decrease in the number of pollen grains, decreased investment in male reproduction and in the probability that ovule fertilization would increase the fitness of the host plant (Miao, 2016).

Threshold grazing intensity may exist because low grazing intensity has no significant effect on reproductive performance (Lee and Bazzaz, 1980; Mueller et al., 2005). Moreover, pollen quality is affected by herbivory damage (Strauss, 1997). Our results also showed that pollen from flowers on heavily browsed plants set fewer pods and ripe seeds compared with pollen from unbrowsed plants (Table 3), and different grazing intensities lead to different pollen performance (Fig. 1). Grazing and the type of pollination and their interaction significantly influenced reproductive success (N`Guessan and Hartnett, 2011). On the other hand, our study found that the proportion of fertilized ovules may not differ depending on the source of pollen from plants browsed at different intensities, and that ovules fertilized by pollen from undamaged plants were more likely to mature. Rosas et al. (2011) suggested that pollen quality is the most likely factor that affects the probability of siring fruits and seeds, such as differences in the speed of germination and/or growth rates of pollen tubes. Moreover, pollen quality could affect the proportion of ovules fertilized under different treatments. At the same time, self-incompatibility in plants may lead to different results for different pollination treatments. That is, autogamy would not usually sire pods and seeds (Xu et al., 1988; Thrall et al., 2014).

In conclusion, biomass allocation to reproductive organs was reduced with increasing grazing intensity. Grazing significantly reduced the number of pollen grains of single flowers, the total number of flowers, riped seeds and the rate of pod-set, and seed mass. Pollen grains from heavily grazed plants that were donated to conspecifics seem to be less likely to set mature seeds if they must compete against pollen grains from non-grazed plants for ovules access.

\section{Acknowledgments}

This work was supported by the National Natural Science Foundation of China under grant (31772235, 31540051); the National Key Research and Development Program (2017YFD0200604, 2016YFD0300205-3, 2018YFD0800301-05).

\section{References}

Brody, A. (1997). Effects of pollinators, herbivores, and seed predators on flowering phenology. Ecology 78, pp. 1624-1631.

Brookshire, E.N.J., Kauffman, J.B., Lytjen, D., Otting, N. (2002). Cumulative effects of wild ungulate and livestock herbivory on riparian willows. Oecologia 132, pp. 559-566.

Buchanan, A.L., Underwood, N. (2013). Attracting pollinators and avoiding herbivores: insects influence plant traits within and across years. Oecologia 173, 473-482.

Cong, X.L., Yang, J.Y., Li, X.M. (2017). Genetic diversity analysis of Caragana Micnphylla LAM. and Caranaga Stenophylla Pojark in inner mongola plateau. Chinese Journal of Grassland 7, pp. 85-92.

Du Tott, J.T., Olff, H. (2014). Generalities in grazing and grazing ecology: using across-guild comparisons to control contingencies. Oecologia 174, 1075-1083.

Feller, I.C. (1996). Effects of nutrient enrichment on leaf anatomy of dwarf Rhizophora mangle L. (Red mangrove). Biotropica $28,13-22$.

Francois, P. (2013). Early physiological responses of Abies alba and Rubus fruticosus to ungulate herbivory. Plant Ecology 214, 127-138. 
González, M.A. (2016). Within-and trans-generational effects of herbivores and detritivores on plant performance and reproduction. Journal of Animal Ecology 85, 283-290.

Gowda, J.H., Palo, R.T. (2003). Age-related changes in defensive traits of Acacia tortilis Hayne. Africa Journal of Ecology 41, 218-223.

He, M., Huang, J.H. (2010). Influence of grazing on seed production of Caragana microphylla. Chinese Journal of Plant Science 45, 59-65.

Juenger, T., Bergelson, J. (1997). Pollen and resource limitation of compensation to herbivory in scarlet gilia, Ipomopsis aggregate. Ecology 78, 1684-1695.

Juenger, T., Bergelson, J. (2000). Does early season grazing influence the effect of self-pollination in scarlet gilia? Ecology $81,41-48$

Kaitaniem, P., Neuvonen, S., Nyyssonen, T. (1999). Effects of cumulative defoliations on growth, reproduction, and insect resistance in mountain birch. Ecology 80, 524-532.

Karban, R., Strauss, S. (1993). Effects of herbivores on growth and reproduction of their perennial host, Erigeron glaucus. Ecology 74, 39-46.

Knight, T.F., Steets, J.A., Vamosi, J.C., Mazer, S.J., Burd, M., Campbell, D.R., Dudash, M.R., Johnston, M.O., Mitchell, R.J., Ashman, T.L. (2005). Pollen limitation of plant reproduction: pattern and process. Annual Review of Ecology, Evolution, and Systematics 36, 467-497.

Krupnick, G.A., Weis, A.E. (1999). The effect of floral herbivory on male and female reproductives success in Isomeris arborea. Ecology 80, 135-149.

Leather, S.R. (2000). Herbivory, phenology, morphology and the expression of sex in trees: who is in the driver's seat? Oikos 90, 194-196.

Lee, T.D., Bazzaz, F.A. (1980). Effects of defoliation and competition on growth reproduction in the annual plant Abutilon theophrasti. Ecology 68, 813-821.

Li, Y.H., Chen, Z.Z., Wang, S.P., Huang, D.H. (1999). Grazing experiment for sustainable management of grassland ecosystem of Inner Mongolia steppe: experimental design and the effects of stocking rates on grassland production and animal liveweight. Acta Agricultural Sinica 7, 173-182 (in Chinese with English abstract).

Liu, L.D., Zhang, L., Gao, Y.B. (2004). Caragana microphylla Lam.. Bulletin Biology 39, 21-22 (in Chinese).

Maleck, K., Dietrich, R.A. (1999). Defense on multiple fronts: how do plants cope with divers enemies? Trends in Plant Science 4, 215-219.

Maschinski, J. (2001). Impacts of ungulate herbivores on a rare willow at the southern edge of its range. Biological Conservation $101,119-130$.

Massad, T.J. (2013). Ontogenetic differences of herbivory on woody and herbaceous plants: a meta-analysis demonstrating unique effects of herbivory on the young and the old, the slow and the fast. Oecologia 172, 1-10.

Miao, F.Z., Xue, W., Guo, Z.G. (2016). Response of niche characteristics of alpine meadow plant populations on the northeastern margin of the Tibetan Plateau to grazing grazing. Acta Pratacultura Sinica 25, 88-97.

Milchunas, D.G., Sternberg, M. (2011). Plant community dynamics in shortgrass steppe with grazing relaxation and imposition by large and small herbivores. Israel Journal of Ecology \& Evolution 57, 23-41.

Mothershead, K., Marquis, R.J. (2000). Fitness impacts of herbivory through indirect effects on plant-pollinator interactions in Oenothera macrocarpa. Ecology 81, 30-40.

Mueller, R.C., Wade, B.D., Gehring, C.A., Whitham, T.G. (2005). Chronic herbivory negatively impacts cone and seed production, seed quality and seedling growth of susceptible pinyon pines. Oecologia 143, 558-565.

Mundim, F.M., Bruna, E.M., Vieira-Neto, E.H.M., Vasconcelos, H.L. (2012). Attack frequency and the tolerance to herbivory of Neotropical savanna trees. Oecologia 168, 405414.

Musser, R.O., Hum-Musser, S.M., Lee, H.K., DesRochers, B.L., Williams, S.A., Vogel, H. (2012). Caterpillar labial saliva alters tomato olant gene expression. Journal of Chemical Ecology 38, 1387-1401.

Nagaike, T. (2012). Effects of grazing by sika deer (Cervus nippon) on subalpine vegetation at Mt. Kita, central Japan. Ecological Research 27, 467-473.

N'Guessan, M., Hartnett, D.C. (2011). Differential responses to defoliation frequency in little bluestem (Schiizachyrium scoparium) in tallgrass prairie: implications for herbivory tolerance and avoidance. Plant Ecology 212, 12751285.

Noy-Meir, I. (1993). Compensating growth of grazed plants and its relevance to the use of rangelands. Ecological Applications 3, 32-34.

Pollice, J., Marcora, P., Renison, D. (2013). Seed production in Polylepis ausralis (Rosaceae) as influenced by tree size, livestock and interannual climate variations in the mountains of central Argentina. New Forests 44, 233-247.

Rebek, K.A., O'Neil, R.J. (2005). Impacts of simulated herbivory on Alliaria petiolata survival, growth, and reproduction. Biolcontrol 34, 283-289.

Rosas, F., Quesada, M., Lobo, J.A., et al. (2011). Effects of habitat fragmentation on pollen flow and genetic diversity of the endangered tropical tree Swietenia humilis (Meliaceae). Biological Conservation 144, 3082-3088.

Ruohomaki, K., Haukioja, E., Repka, S., Lehtila, K. (1997). Leaf value: effects of damage to individual leaves on growth reproduction of mountain birch shoots. Ecology 78, 2105-2117.

Rusch, G.M., Skarpe, C., Halley, D.J. (2009). Plant traits link hypothesis about resource-use and response to herbivory. Basic \& Applied Ecology 10, 466-474.

Schemske, D.W. (1988). Plant-animal interactions and fruit production in a neotropical herb: a path analysis. Ecology 69, $1128-1137$.

Sell, A.F. (2000). Morphological defenses induced in situ by the invertebrate predator Chaoborus: comparison of responses between Daphnia pules and D. rosea. Oecologia 125, 150-160.

Simms, E.L., Rausher, M.D. (1987). Costs and benefits of plant resistance to herbivory. American Naturalist 130, 570-581.

Solomon, B.P. (1986). Sexual allocation and andromonoecy: resource investment in male and hermaphrodite flowers of Solanum carolinence (Solanaceae). American Journal of Botany 73, 1215-1221.

Stephenson, A.G. (1982). The role of the extrafloral nectaries of Catalpa speciosa in limiting herbivory and increasing fruit production. Ecology 63, 663-669.

Strauss, S. (1997). Floral characters link herbivores, pollinators, and plant fitness. Ecology 78, 1640-1645.

Thrall, P.H., Encinasviso, F., Hoebee, S.E., et al. (2014). Life history mediates mate limitation and population viability in self-incompatible plant species. Ecology \& Evolution 4, 673 687.

van Kleunen, M., Ramponi, G., Schmid, B. (2004), Effects of herbivory simulated by clipping and jasmonic acid on Solidago Canadensis. Basic and Applied Ecology 5, 173-181.

Vazquez, D.P., Simberloff, D. (2004). Indirect effects of an introduced ungulate on pollination and plant reproduction. Ecological Monographs 74, 281-308.

Wang, L.H., Liu, W., Wang, J.N., et al. (2015). Compensatory growth of grassland communities, stratification and species under different cutting strengths. Acta Pratacultura Sinica Sinica 24, 35-42.

Wang, S.P., Li, Y.H., Wang, Y.F., Chen, Z.Z. (2001). Influence of different stocking rates on plant diversity of Artemisia frigida community in Inner Mongolia steppe. Acta Botany Sinica 43, 89-96 (in Chinese with English abstract).

Wang, S.P., Li, Y.H., Wang, Y.F., Han, Y.H. (1998). The succession of Artemisia frigida rangeland and multivariation analysis 
under different stocking rates in Inner Mongolia. Acta Agricultural Sinica 6, 299-305 (in Chinese with English abstract).

Xu, L.R., Hao, X.Y., Yang, X.L., Li, Y.J. (1988). On the hybridization and classification of Caragana korshinskii Kom. and $C$. intermedia Kung et H. C. Fu. Abstracts of the papers presented at the $55^{\text {th }}$ Anniversary of the Botanical Society of China, pp. 188.
Zhang, Z., Wang, S.P., Patton, B., Nyren, P., Jiang, G.M. (2007). Responses of Artemisia frigida and Leymus chinensis to sheep saliva. Journal of Arid Environment 70, 111119. 